\title{
Enhancing State Responsibility from Environmental Implications of the South China Sea Dispute
}

\author{
Amrisha Pandey and Surya P. Subedi
}

\section{Introduction}

In response to the People's Republic of China's (PRC) assertion of sovereignty over certain islands and maritime features in the South China Sea and conduct in respect of these features, the Philippines resorted to the compulsory dispute settlement mechanism contained in the 1982 United Nations Convention on the Law of the Sea (LOSC) $)^{1}$ against the People's Republic of China. ${ }^{2}$ A Tribunal was constituted under Annex VII of the LOSC to hear the case. ${ }^{3}$ Both the PRC and the Republic of China (Taiwan) refused to accept that the Tribunal had jurisdiction on the matters referred to it by the Philippines. ${ }^{4}$ Ultimately, the Tribunal found it had jurisdiction ${ }^{5}$ and delivered its decision on the merits on 12 July 2016, holding that the PRC had breached Articles 192 and 194(5) of the LOSC through its failure to protect and preserve the marine environment, including harm caused by activities carried out under the control of the State. ${ }^{6}$ As a result of the PRC's non-participation in the proceedings and subsequent non-recognition of the decision, questions now arise concerning the implementation of the Tribunal's award and the implications that this has for the protection of the marine environment.

There is no mechanism under the LOsc for enforcing such awards, and general international law lacks any executive or execution agency that can enforce the rulings of international courts and tribunals. This is significant not only for

11833 UNTS 3 (LOSC).

2 In the Matter of an Arbitration between the Republic of the Philippines and the People's Republic of China, Award on Jurisdiction and Admissibility of 29 October 2015 (PCA case No. 2013-19) (hereinafter the scs Jurisdiction).

3 Ibid, para 12.

4 Ibid, para 89 .

5 Ibid, para 413 .

6 South China Sea Arbitration (The Republic of the Philippines $v$ The People's Republic of China), Award, 12 July 2016, PCA Case No 2013-19 (hereinafter the SCs Merits), para 993. 
the rule of law, but also because it undermines the protection of the environment. The activities of States in the South China Sea (scs) are not only relevant to the disputes that exist between the States within the region, but also to the wider issue of the protection and preservation of the marine environment therein. At present, 8o percent of the reefs in the SCS region are threatened and classified as endangered. Studies suggest that by 2030, 9o percent of the reefs will be at risk due to human activities and the change in climatic conditions. ${ }^{7}$ Reefs act as the natural carbon dioxide sink and host a vast diversity of the flora and fauna which is essential for the present and future generations. Human activities in the fragile ecosystem are a potential major threat to biodiversity. The impact of these activities is capable of causing a change in climatic conditions, making it a potential threat and a concern common to humankind. ${ }^{8}$ Furthermore, disputes concerning the sovereignty over the islands and other maritime features of the SCS and the legal status of the waters around them have raised the political temperature in the region. ${ }^{9}$ Since nearly $70-$ 8 o percent of world trade passes through the waters of the scs, ${ }^{10}$ other States are concerned about rising tensions in the region and its impact on the future of freedom of navigation in the region. ${ }^{11}$

The purpose of this chapter is not to delve into the territorial or sovereignty disputes in the scs, but to examine the implications of the decision by the State in the form of State activities such as fishing and marine construction for the marine environment and to assess the adequacy of international law to mitigate environmental harm by bringing States within the frame of international responsibility. More specifically, we argue that the threat to marine

J McManus, E Gomez, S Wells, S Norman and S Jupiter, Coral Reefs of the SCS: A Need for Action (Briefing document prepared by the International Society for Reef Studies (ISRS), July 2016), http://coralreefs.org/wp-content/uploads/2019/o1/ISRS-South-China-SeaBriefing-21Nov2016.pdf (all websites accessed 8 October 2020 unless otherwise noted).

E Brown Weiss, 'Nature and the Law: The Global Commons and the Common Concern of Humankind', Sustainable Humanity, Sustainable Nature: Our Responsibility, Pontifical Academy of Sciences, Extra Series 41; Pontifical Academy of Social Sciences, Acta 19 (Vatican City, 2014).

9 J Kim, 'Territorial Disputes in the South China Sea: Implications for Security in Asia and Beyond' (2015) 9(2) Strategic Studies Quarterly 107-141; see also, N Hong, 'The South China Sea Dilemma: A Political Game of International Law' (2016) 4(6) Journal of Political Risk, http://www.jpolrisk.com/the-south-china-sea-dilemma-a-political-gameof-international-law/.

10 China Power Team, 'How Much Trade Transits the South China Sea?' China Power (2 August 2017, updated 26 August 2020), https://chinapower.csis.org/much-trade-transitssouth-china-sea/; accessed 29 May 2019. Ibid. 
biodiversity should be regarded as a threat common to humankind and therefore it requires stronger community orientated responses. This is because biodiversity provides various services for human beings such as it supports food diversity, dietary health, livelihood sustainability, and it provides medicinal benefits and it is essential for climate change adaptation. ${ }^{12}$ In keeping with the theme of this book, and Freestone's research, we see this tension between individual State interests and community interests. Law of the sea has its origins in the former, and yet seeks to advance the latter. This is the balancing of interests that is at the heart of the Convention. Here there is no strict demarcation of individual/community interests, but rather a dynamic legal framework that evolves according to contemporary interests and new understandings of human/ocean interactions.

Section 2 explores the environmental implications of the island building and harmful fishing on the marine environment using the Submission 11 and 12(b) of the scs dispute as a case study. ${ }^{13}$ These submissions mainly deal with the alleged failure by China to protect and preserve the marine environment. ${ }^{14}$ The aim of this section is to demonstrate the implications of State activities irrespective of their jurisdiction on the marine environment and how it affects marine biological diversity and the wider international community. In section 3, we examine briefly, the 'Chinese position' as advanced by the Chinese Society of International Law in order to understand the position of the State in breach of its international obligations. ${ }^{15}$

As Desierto notes, whether a State complies with an international decision may depend upon a range of factors beyond pure self-interest, including,

12 Convention on Biological Diversity (СвD), 'The Importance of Biodiversity to Human Health', сонав Initiative Policy Brief 1, (UN CвD COP 10 Policy Brief, October 2010).

13 R Beckman (ed), Beyond Territorial Disputes in the South China Sea: Legal Frameworks for the Joint Development of Hydrocarbon Resources (Edward Elgar, 2013); see also, C-J Cheng, 'Selected Bibliographic and Research Resources on the Legal Status of the SCS and Dongsha (Pratas), Xisha (Paracel), Zhongsha (Macclesfield Bank) and Nansha (Spratly) Islands' (2011) 8 Soochow Law Journal 41-171; S Yee, 'The South China Sea Arbitration (The Philippines v. China): Potential Jurisdictional Obstacles or Objections' (2014) 13(4) Chinese Journal of International Law 663-739; J Shen, 'China's Sovereignty over the South China Sea Islands: A Historical Perspective' (2002) 1(1) Chinese Journal of International Law 94-157; E Franckx and M Benatar, 'Dots and Lines in the South China Sea: Insights from the Law of Map Evidence' (2012) 2 Asian Journal of International Law 89-118; TN Dang, 'Fisheries Cooperation in the South China Sea and the (Ir)relevance of the Sovereignty Question' (2012) 2 Asian Journal of International Law 59-88.

14 scs Merits, above (n 6), paras 815-993.

15 Chinese Society of International Law (CSIL), 'The SCS Arbitration Awards: A Critical Study' (2018) 17(2) Chinese Journal of International Law 207-748. 
strategic co-operation and concern for international reciprocity; reputational concerns; its sense of identity with shared acceptable norms of international behaviour; or the State's sense of legitimacy and fairness. These factors point clearly towards the wider conceptions of community interests. This analysis is important because loss of biological diversity is argued to be of wider importance beyond the mere parties to the dispute, thus, calling for the collaborative input from the international community of States to categorise such concerns as the concern common to humankind and to devise a mechanism to address the same. ${ }^{16}$ This issue of wider community interest is dealt with in Section 4, further highlighting the reason why disputes with significant environmental implications cannot be managed in isolation, and emphasizing that effective resolution requires some degree of cooperation and burden-sharing with the international community. This aspect of State responsibility concerning obligations owed to the international community is discussed in Section 5 , whereas Section 6 is devoted to discussing other means to cooperatively manage, protect or conserve marine environment. Section 7 draws some key points from this analysis, emphasizing the importance of common concerns, even in what appears to be a traditional bilateral dispute.

\section{Environmental Aspects of the scs Decision}

The sCs is a semi-enclosed sea bordering eight States, six of which have competing or overlapping territorial and maritime jurisdictional claims in the disputed area. Such disputes are complicated by the presence of hundreds of maritime features, either above or below water. ${ }^{17}$ The main groups of islands and other maritime features are as follows: The Paracel Islands; the Pratas Islands; Scarborough Reef; the Natuna Islands; and the Spratly Islands. The States and entities ${ }^{18}$ making competing claims over these islands and other maritime features in the scs are Brunei, China, Malaysia, the Philippines,

16 DA Desierto, 'Enforcement Options and Paths to Compliance: Disputants and Global Stakeholders in Philippines v. China' (2018) 8(1) Asian Journal of International Law $64-75,66$.

17 R Pedrozo, 'Close Encounters at Sea: The USNS Impeccable Incident' (2009) 62(3) Naval War College Review 101.

18 This chapter refers to Taiwan as an 'entity' due to its special political status. See further, A Serdy, 'Bringing Taiwan into the International Fisheries Fold: The Legal Personality of a Fishing Entity' (2004) 75 British Yearbook of International Law 183-221. 
Taiwan, and Vietnam. ${ }^{19}$ Two others States bordering the sea, Indonesia and Singapore, have no competing claims over these islands, although Indonesia has raised concerns about the delimitation of the maritime zones in the area with China. ${ }^{20}$ Cambodia and Thailand are located along the Gulf of Thailand's extension of the scs but have no competing claims over these islands or over the maritime zones.

China has claimed sovereignty over a number of islands and other maritime features within the U-shaped 'nine-dash' line around the scs. Other States have disputed this. ${ }^{21}$ Attempts have been made to address the longstanding disputes at the political level. ${ }^{22}$ This includes the China - AsEan Declaration on the Conduct of Parties in the SCS of November 2002, which places an emphasis on resolving the disputes through negotiations. Perhaps recognizing the political asymmetries involved, the Philippines preferred to resort to the legal dispute settlement mechanism contained in the Losc. The Philippines went to great lengths to ensure that its application did not raise questions concerning territorial or sovereignty disputes with China since these would be excluded from the jurisdiction of the Tribunal. Instead, its claims focused on meaning and the implementation of the provisions of the LOSC. Of particular concern to the present chapter are Philippine's Submissions 11 and 12(b), which concern the alleged failure of China to protect and preserve the marine environment. Philippines argued that China had violated the Convention by interfering with the exercise of the Philippines' sovereign rights and freedoms under the Convention and that construction and fishing activities have harmed the marine environment.

For the purposes of this chapter, the dispute is analysed under two headings: environmental implications of the construction activities; and environmental implications of the harmful fishing and trade with endangered species. In the subsequent sections, the present and future impacts of State/s activities

19 Council on Foreign Relations, 'China's Maritime Disputes' (A C F R InfoGuide Presentation), https://www.cfr.org/interactives/chinas-maritime-disputes?cid=otr-marketing_usechina_sea_InfoGuide\#!/chinas-maritime-disputes?cid=otr-marketing_use-china_ sea_InfoGuide; see also, YH Song and S Tonnesson, 'The Impact of the Law of the Sea Convention on Conflict and Conflict Management in the South China Sea' (2013) 44(3) Ocean Development \& International Law 235-269; SP Subedi, 'The Disputes in the South China Sea and the United Nations Convention on the Law of the Sea' (2017) 14(1) Soochow Law Journal $15^{-41 .}$

20 VL Forbes, Indonesia's Delimited Maritime Boundaries (e-book: Springer-Verlag, 2014).

21 Council on Foreign Relations, above (n 19).

22 MJ Valencia, 'The East China Sea Dispute: Context, Claims, Issues, and Possible Solutions' (2007) 31(1) Asian Perspective 127-167. 
will be analysed to help understand their impact on the environment, and the manner in which they affect marine biological diversity and the marine ecology of the SCs, since no part of the ocean today is untouched by the impact of anthropogenic activities. Therefore, taxonomical identification of the pressures created by the human activities on the marine environment are presented as follows to better understand and regulate these activities: ${ }^{23}$

(a) Climate change (and ocean acidification, including the resulting changes in salinity, sea-level, ocean heat content and sea-ice coverage, reduction in oxygen content, changes in ultra-violet radiation);

(b) Human-induced mortality and physical disturbance of marine biota (such as capture fisheries, including by-catch), other forms of harvesting, accidental deaths such as through collisions and entanglement in discarded nets, disturbance of critical habitat, including breeding and nursery areas);

(c) Inputs to the ocean (these can be broken down according to the nature of their effects: toxic substances and endocrine disruptors, waterborne pathogens, radioactive substances, plastics, explosives, excessive nutrient loads, hydrocarbons). Remobilization of past inputs also needs to be considered;

(d) Demand for ocean space and alteration, or increase in use, of coasts and seabed (conflicting demands lead to both changes in human use of the ocean and changes to marine habitats);

(e) Underwater noise (from shipping, sonar and seismic surveys);

(f) Interference with migration from structures in the sea or other changes in routes along coasts or between parts of the sea and/or inland waters (for example, wind-farms, causeways, barrages, major canals, coast reinforcement, etc.); and

(g) Introduction of non-native species.

The following sub-sections investigate the issues arising from submission number 11 and $12(\mathrm{~b})$ in the scs dispute.

\subsection{Environmental Implications of Construction Activities}

The sCs is rich in natural heritage, and a number of scientists hold the opinion that artificial island building for civilian or military purposes might cause serious and irreversible damage to the marine biological diversity of the area

23 P Bernal, B Ferreira, L Inniss et al., 'Chapter 54: Overall Assessment of Human Impact on the Oceans' in L. Inniss and A Simcock (Joint Coordinators), The First Global Integrated Marine Assessment: World Ocean Assessment I (UN, 2016). 
and is harmful for the marine environment. ${ }^{24}$ The construction activities present three threats: shoreline erosion, changes to water currents, and the direct impact on the marine environment. ${ }^{25}$ Based on the information gathered by satellite, computer-modelling data, and previous studies of human impacts on coral reefs, scientists have begun to raise global awareness of possible harmful and irreparable damage caused to the fragile ecosystem due to human activities. ${ }^{26}$

In the scs case, the Tribunal exercised its powers under its rules of procedure to take all appropriate measures in order to establish the facts of the case. ${ }^{27}$ This includes requesting the parties to produce the documents, evidence or exhibits; and appointing an independent expert to report on specific issues. On 29 February 2016, the Tribunal appointed Dr Ferse as an expert on coral reefs. The Tribunal later appointed two additional experts: Professor Peter Mumby and Dr Selina Ward. Pursuant to Article 24(4) of the Rules of Procedure, a combined report (Ferse Report) was submitted to the Tribunal, assessing the potential environmental consequences of construction activities on the scs. ${ }^{28}$ The Philippines expressed that it had no comments and the PRC did not respond.

24 C Carroll, 'Protecting the South China Sea: Chinese Island-Building and the Environment' Foreign Affairs (9 June 2017), https://www.foreignaffairs.com/articles/china/2017-06-o9/ protecting-south-china-sea; accessed 10 July 2018; see also, K Ghaffari, T Habibzadeh, MN Asfad and R Mousazadeh, 'Construction of Artificial Islands in Southern Coast of the Persian Gulf from the Viewpoint of International Environmental Law' (2017) 10(2) Journal of Politics and Law 264-275; F Bulleri and MG Chapman, 'The Introduction of Coastal Infrastructure as a Driver of Change in Marine Environments' (2010) 47 Journal of Applied Ecology 26-35; SY Chee, AG Othman, YK Sim et al., 'Land Reclamation and Artificial Islands: Walking the Tightrope between Development and Conservation' (2017) 12 Global Ecology and Conservation 80-95.

25 Ecological Effects of Island Construction in the Persian Gulf, 'Ecological Effects of Island Construction' (n.d.), https://sites.google.com/a/owu.edu/ecological-effects-of-islandconstruction-in-the-persian-gulf/en.

26 CR Wilkinson and RW Buddemeier, Global Climate Change and Coral Reefs: Implications for People and Reefs (Report of the UN EP-IOC-ASPEI-UCN Global Task Team on the Implications of Climate Change on Coral Reefs) (IUCN, 1994); see also M Ives, 'Artificial Islands: The Rising Environmental Toll of China's Offshore Island Grab'YaleEnvironment 360 (1o October 2016), https://e36o.yale.edu/ features/rising_environmental_toll_china_artificial_islands_south_china_sea; accessed 1 March 2019.

27 scs Merits, above (n 6), paras 84-105.

28 SCA Ferse, P Mumby, and S Ward, Assessment of the Potential Environmental Consequences of Construction Activities on Seven Reefs in the Spratly Islands in the South China Sea, Independent Expert Report (26 April 2016) (Ferse Report), https://pcacases.com/web/ sendAttach/1809. 
The Philippines appointed Professors McManus and Carpenter as experts to examine harmful impacts of the State activities in the scs. The study conducted by McManus suggests that the dredging caused by large ships affects the coral reefs, deep water channels and harbours. ${ }^{29}$ Similar harm is caused by smaller ships dredging shallow water around reef flats and lagoons and by digging corals using propellants. ${ }^{30}$ These human activities are harmful because they can cause a change in wave patterns, altering the growth of red algae that is essential for calcification and sedimentation of coral reef. Dredging potentially obstructs their development and can cause permanent damage to the reefs. The study conducted by Carpenter and McManus further stated that island building and dredging had already damaged 10 percent of the shallow reef area of the Spratly Islands. ${ }^{31}$ Part IX of the Ferse Report confirmed that the Philippines experts provided generally accurate descriptions of the construction impacts, based on the available information. However, it noted that in some cases the damage was overstated, but in others the potential damage might have been underestimated. ${ }^{32}$

Significantly, the Tribunal accepted the scientific claims concerning the ecological richness, connectivity and importance of the marine environment of the SCs. ${ }^{33}$ This corresponds to a much wider body of literature on the subject. Specifically, coral reefs in the Spratly Islands and other offshore regions, including the Paracel Islands and Scarborough Shoal, supply larvae for fisheries that feed hundreds of millions of people. The Spratly Islands, including its

29 Dredging can be defined as 'excavation-type' work, where a dredger removes sediments from an estuary, waterway or ocean floor. This work can include cleaning, deepening, or widening of a body of water using a scoop or suction device. In essence, the dredging process consists of the following three elements: excavation, transport of excavated material, and use or disposal of dredged material. Dredger vessels or ships of various sizes were used for artificial island building.

30 KE Carpenter, Eastern South China Sea Environmental Disturbances and Irresponsible Fishing Practices and Their Effects on Coral Reefs and Fisheries, 22 March 2014, South China Sea Arbitration, PCA Case No 2013-19, Memorial of the Philippines, Vol viI, Annex 24O, 39 (First Carpenter Report); KE Carpenter and L Ming Chou, Environmental Consequences of Land Reclamation Activities on Various Reefs in the South China Sea, 14 November 2015, in South China Sea Arbitration, PCA Case No 2013-19, Supplemental Documents of the Philippines, Vol II (19 November 2015), Annex 699, 3, 26-27 (Second Carpenter Report); JW McManus, Offshore Coral Reef Damage, Overfishing and Paths to Peace in the South China Sea (rev. ed., 21 April 2016) (McManus Report) 10-11, https://pcacases.com/web/ sendAttach/1917.

31 McManus Report, ibid text at footnote 98, and Declaration of Prof. KE Carpenter appended to the Report.

32 Ferse Report, above (n 28), Part XI-Conclusion.

33 scs Merits, above (n 6), paras 823-825. 
12 main islets and more than 100 coral reefs, are of great significance due to their geographical location and rich biological diversity. ${ }^{34}$ A scientific study conducted by Ives corroborates the findings of the McManus Report, and is of the opinion that 'the Spratlys are biological 'stepping stones' for successive generations of corals and fish meaning that the larvae produced here float hundreds of miles toward the Spratlys on ocean currents and stop in eddies near their corals to breed'. ${ }^{35}$ Also, Wilkinson observes that the Spratly Islands are 'positioned very neatly to transfer biodiversity' across open water. ${ }^{36}$ The larvae produced by the reefs around the Spratlys is a valuable source of food for many migratory species such as tuna. The migratory route of the species travelling through the SCS and reaching the Indian Ocean feed themselves on the larvae produced in waters around the Spratlys. Therefore, damage to the reef will also cause a change in migratory patterns and threaten the existence of species that depend upon their wider ecosystem function. ${ }^{37}$ The long-term impacts could be devastating for the rich biological diversity of the region.

The reefs are also a living seed bank that could help the region's marine community deal with the long-term impacts of climate change. ${ }^{38}$ They are ecologically engineered structures capable of providing wave reduction benefits; it has been argued that the reefs reduce wave energy by up to 97 percent. By absorbing and or breaking up waves, they act as buffers and act as the coastal defence mechanism. This can mitigate exposure to rising sea levels and stronger storms driven by climate change. ${ }^{39}$ Additionally, reefs play a crucial or assistive role in the life cycle of various marine species thereby helping protect marine biological diversity. Reefs play an important role in fighting climate change and maintaining the marine biological diversity; ongoing harm to reefs

34 G Torode, "Paving Paradise': Scientists alarmed over China island building in disputed sea' Reuters (25 June 2015), https://www.reuters.com/article/us-southchinaseachina-environment-insig-idUSKBNoP5oUB20150625.

35 Ives, above (n 26 ).

36 See C Wilkinson, L-DeVantier, T Talaue-McManus and D Lawrence, South China Sea, GIWA Regional Assessment 54 (UNEP, 2005); see also, International Coral Reef Initiative (ICRI), 'Our Networks', https://www.icriforum.org/our-networks/.

World Meteorological Organization (wMo), Climate, Carbon and Coral Reefs, wmo-No 1063 (wм0, 2010); see also BD Keller, DF Gleason, E McLeod et al., 'Climate Change, Coral Reef Ecosystems, and Management Options for Marine Protected Areas' (2009) 44(6) Environment Management 1069-1088.

38 wMo, above (n 37).

39 R McLendon, 'How Coral Reefs Can Help Us Endure Climate Change' Treehugger (13 June 2018), https://www.mnn.com/earth-matters/wilderness-resources/blogs/ how-coral-reefs-can-help-us-endure-climate-change. 
is alarming the scientific community. ${ }^{40}$ As a consequence, a resolution was passed by the UN General Assembly in 2010 recognizing the importance of the coral reefs for their ecology, as well as for the humans, and calling for the protection of coral reefs for sustainable livelihoods and development. ${ }^{41}$ Various multilateral environmental agreements address the protection of coral reefs directly or indirectly. This includes the Stockholm Convention on Persistent Organic Pollutants, ${ }^{42}$ the Global Programme of Action for the Protection of the Marine Environment from Land-based Activities (GPA), ${ }^{43}$ the Convention on Biological Diversity, ${ }^{44}$ the Ramsar Convention on Wetlands, ${ }^{45}$ and the Convention on International Trade in Endangered Species of Wild Fauna and Flora (CITEs). ${ }^{46}$

The growing interest of littoral States in the SCs is driven by the zeal for exploitation of marine resources and extraction of natural gas and oil resource for economic and political gains. ${ }^{47}$ Foreign States are equally interested due

40 S Van Sant, 'Marine Biologists: Artificial Islands Devastating South China Sea Ecosystems' VOA (28 January 2016), https://www.voanews.com/east-asia-pacific/ marine-biologists-artificial-islands-devastating-south-china-sea-ecosystems.

41 United Nations General Assembly, Resolution 65/150: Protection of coral reefs for sustainable livelihoods and development, adopted 2o December 2010. This called upon the Secretary General to make a report, subsequently published in 2011: UNGA, Protection of coral reefs for sustainable livelihoods and development: Report of the Secretary-General, UN Doc A/66/298 (12 August 2011).

42 Adopted 22 May 2001, 2256 UNTS 119.

43 UNEP, Global Programme of Action for the Protection of the Marine Environment from Land-based Activities (GPA), UneP Doc (ocA)/LbA/IG.2/7 (5 December 1995). The GPA was adopted by over 108 governments, including Australia and the European Commission, in Washington DC on 3 November 1995 .

44 Adopted 5 June 1992, 1760 UnTS 79; see also СвD Secretariat, 'Notification: Launch of the Global Coral Portal', Doc SCBD/sssF/BSPG/As/JL/JA/87674 (9 November 2018), https:// www.cbd.int/doc/notifications/2018/ntf-2018-o93-marine-en.pdf.

451971 Convention on Wetlands of International Importance especially as Waterfowl Habitat (Ramsar Convention), 996 UnTS 245, as amended by the Paris Protocol (3 December 1982) and Regina Amendments (28 May 1987); see also Resolution IX.4: The Ramsar Convention and conservation, production and sustainable use of fisheries resources, adopted at 9 th Meeting of the Conference of the Parties to the Convention on Wetlands (Kampala, Uganda, 8-15 November 2005).

46 Adopted 3 March 1973, 993 UNTS 243; see also, ICRI, 'Recommendation on International Trade in Corals, Coral Reef Species and Related Products A Draft Motion on International Trade in Coral Reef Species and Related Products', approved at the ICRI General Meeting, Monaco, 12-15 January 2010, https://www.icriforum.org/documents/recommendationon-international-trade-in-corals-coral-reef-species-and-related-products/.

47 Csis South China Sea Expert Working Group, 'A Blueprint for Cooperation on Oil and Gas Production in the South China Sea' Asia Maritime Transparency Initiative Update 25 
to the geopolitical importance of the region. ${ }^{48}$ Marine exploitation activities are expected to grow in the short-term, raising demands for improved regulation and protection. ${ }^{49}$ However, it has also led to calls from the scientific community that the conservation and protection of the reefs is a lot cheaper and effective than other human-engineered alternatives such as sea walls. ${ }^{50}$ Similarly, island building for military or other purposes creates a risk of pollution which needs to be planned and managed very carefully. Construction of artificial islands can obstruct sunlight which is essential for the development of the coral. Thus, construction activities not only destroy and cause harm to existing corals but they can impede their natural development causing longterm and irreversible harm. Given the ecological positioning and importance of the reefs and the role they play, a threat to their survival may be considered as a threat shared by the international community. The wider impact of threats to regional seas from local activities was accepted by the Tribunal, although it fell short of observing the global scale of threats to biodiversity. ${ }^{51}$

\subsection{Environmental Implications of Harmful Fishing and Trade with Endangered Species}

The Philippines' claim of harmful fishing by Chinese fishers did not just limit itself to overfishing but encompassed the holistic impact of the activity: the means of fishing, and their impact on the marine environment, the rights of the neighbouring States, as well as the impacts on present and future generations. Philippines' claims related to harmful practices to harvest giant clams, shark, sea turtle, giant oysters, eels and large pieces of highly ornamental coral. ${ }^{52}$ A report by the Philippine's armed forces report suggests that the fishing was

July 2018), https://amti.csis.org/a-blueprint-for-cooperation-on-oil-and-gas-productionin-the-south-china-sea/.

48 MA Kuo, 'The Geopolitics of Oil and Gas in the South China Sea: Insights from Eufracia Taylor and Hugo Brennan' The Diplomat (12 December 2018), https://thediplomat.com/ 2018/12/the-geopolitics-of-oil-and-gas-in-the-south-china-sea/.

49 C Carswell, 'Unique Oil Spill in East China Sea Frustrates Scientists' (2018) 554 Nature 17-18.

50 M Beck, 'Coral Reefs: The Seawall That Nature Built' National Geographic Society Newsroom (13 May 2014), https://blog.nationalgeographic.org/2014/05/13/coral-reefs-theseawall-that-nature-built/.

51 Scs Jurisdiction, above (n 2) para 825: "This means that the impact of any environmental harm occurring at Scarborough Shoal and in the Spratly Islands may not be limited to the immediate area, but can affect the health and viability of ecosystems elsewhere in the South China Sea'.

$5^{2}$ Ibid para $826-851$, where the Tribunal summarizes more extensive evidence presented by the Philippines. 
being conducted using cyanide and sodium cyanide. ${ }^{53}$ That a Chinese foreign ministry official expressed concerns to the Philippines regarding the practice of dynamite fishing, ${ }^{54}$ shows some shared concern about the use of destructive fishing techniques on the marine environment and the biological diversity.

Article 194(5) of the LosC deals with the necessary steps which should be taken by States Parties to protect and preserve rare or fragile ecosystems as well as the habitat of depleted, threatened or endangered species and other forms of marine life. This article implies that concerned States are responsible for ensuring the environmental protection taking into account all possible considerations whether explicitly stated in the Convention or not. The Tribunal in Chagos Marine Protected Area Arbitration (Mauritius v the United Kingdom) confirmed that Part XII is 'not limited to measures aimed strictly at controlling marine pollution', which while 'certainly an important aspect of environmental protection ... is by no means the only one'.55 Building on the decision in Chagos, the Philippines argued that the activities of the PRC constituted a threat to the rare and fragile ecosystem of the scs. ${ }^{56}$

In addition to the harmful fishing, it was alleged that China harvested endangered species, something regarded as one of the biggest threats to the biodiversity. ${ }^{57}$ The act and the means of harvesting were found to be unsustainable and a threat to the marine biological diversity in this case. The Tribunal was satisfied on many occasions the Chinese vessels had been involved in harvesting threatened and endangered species. ${ }^{58}$ It noted that it considers that the duty to prevent the harvest of endangered species followed from Article 192 of the LOSC (read in the context of other applicable international law). The Tribunal considered that this general obligation is given particular shape in Article 194(5), ${ }^{59}$ and that both are applicable to the scs. Appendix I of the CITES lists all species of sea turtle found in the region as endangered species which require special protection. ${ }^{60}$ The obligations created by the CITES is of nearly

\footnotetext{
$53 \quad$ Ibid para 845 .

54 Ibid para 913(a).

55 Chagos Marine Protected Area Arbitration (Mauritiusv United Kingdom), Award, 18 March 2015, PCA Case No 2011-03, paras 320, 538.

56 scs Merits, above (n 6) para 945; see also South China Sea Arbitration, PCA Case No 201319, The Philippines' Written Responses (11 March 2016), Annex 872: China State Ocean Administration, 'Construction Activities at Nansha Reefs Did Not Affect the Coral Reef Ecosystem (10 June 2015).

57 E Di Minin, TM Brooks, T Toivonen et al., 'Identifying Global Centers of Unsustainable Commercial Harvesting of Species' (2019) 5(4) Science Advances eaau2879.

58 scs Merits, above (n 6), para 950.

59 Ibid para 959 .

6o CITES above ( $\mathrm{n} 46)$
} 
universal adherence which applies to the parties of this dispute as well. This is why the Tribunal considered such obligations as part of the general corpus of international law that must have an automated bearing on the provisions of Articles 192 and 194(5) of the Losc. ${ }^{61}$ Giant clams and the coral found in the Spratly Islands are listed in Appendix II of the CITES, which suggest that they are also considered endangered species although they might not be subject to the same level of protection as in case of the species listed in Appendix I ${ }^{62}$

\subsection{Summary Remarks on Environmental Aspects of the scs decision}

Both construction activities and harmful fishing practices are threats to the habitat of the endangered species; they can cause an unprecedented threat to the biological diversity of the region. Biodiversity is considered to be the integration of biological variability across all scales, from the genetic, through species and ecosystems, to landscapes. ${ }^{63}$ It is often believed that the ecosystem approach is the best means to conserve processes and habitat, and hence biodiversity. ${ }^{64}$ For example, the Secretariat of the Convention on Biological Diversity has recognized the ecosystem approach as the cardinal principle for the implementation of the Convention. ${ }^{65}$

In the SCS dispute, the activities conducted by the PRC by itself or by means of organs of the State were alleged by the Philippines and agreed by the Tribunal to have violated the substantial, as well as procedural obligations specified in Article 192 and 194 of the LOsC. ${ }^{66}$ Given the relationship between Article 192 and 194, the concept of due diligence becomes increasingly important. This is because it opens the way for a much more calibrated and nuanced approach to responsibility, one that perhaps better reflects the complexities of harm to complex natural systems. Historically, harmful conduct has often been considered in isolation of individual agreements. However, due diligence concerns more objective standards of conduct and this can be understood in light of wider normative measures, that is, those measures 'necessary' to

\footnotetext{
61 Ibid.

62 Ibid.

63 BH Walker, 'Biodiversity and Ecological Redundancy' (1992) 6 Conservation Biology 18-23; see also B Walker, 'Conserving Biological Diversity through Ecosystem Resilience' (1995) 9 Conservation Biology $747-75^{2}$.

64 JF Franklin, 'Preserving Biodiversity: Species, Ecosystems, or Landscapes?' (1993) 3 Ecological Society of America 202-205.

65 See Secretariat of the СвD, The Ecosystem Approach (свD Guidelines) (Secretariat of the CBD, 2004) 3 .

66 scs Award, above (n 6) paras 992-993.
} 
achieve generally defined environmental objectives - such as Article $192 .{ }^{67}$ Due diligence is the standard of care which is reasonable and proportional to the assessed harm and against which the fault is assessed. It requires an investigation of whether the reasonable standard of care has been applied by the State in a particular case to avert or mitigate the harm caused by its acts or omissions. ${ }^{68}$ As explained by the commentary to Article 3 of the International Law Commission (ILC) Draft Articles on Prevention of Transboundary Harm from Hazardous Activities, the due diligence standard should be 'appropriate and proportional to the degree of risk of the transboundary harm'.69 And even if the precise content of due diligence is unclear, its requirements are to be defined and held to the international standard and not in accordance with the standards under national law. ${ }^{70}$ The degree of due diligence hinges on the primary rules, and changes in primary rule affects the standard of expected care. Arguably, over a longer period of time, standards of conduct can evolve either under customary international law, changes in treaty regimes or through institutional practices, such as those of the United Nations. ${ }^{71}$ We return to the question of liability for complex environmental harms in sections 4 and 5 below. Before doing so, it is necessary to consider the position of China in the SCS dispute, and particularly the way in which the Chinese position has focused, inter alia, on the way the Tribunal approached standards of environmental responsibility.

67 scs Merits, above (n 6) 959 .

68 T Stephens (Rapporteur) and D French (Chair), 'ILA Study Group on Due Diligence in International Law: Second Report (July 2016).

69 ILC, Draft Articles on Prevention of Transboundary Harm from Hazardous Activities, with commentaries, Yearbook of the International Law Commission, 2001, vol II, Part Two, p 154, commentary to Article 3, para 11; see also, UN Human Rights Council, Guiding Principles on Business and Human Rights: Implementing the United Nations 'Protect, Respect and Remedy' Framework, UN Doc A/HRC/17/31 (21 March 2011), Principle 17(b) (explicitly stating that due diligence 'will vary in complexity with ... the risk of severe human rights impacts), Principle 7 (requiring States to pay particular attention to the human rights-related risks of businesses operating in conflict-affected areas), Principle 3 (assessing the adequacy of laws in light of evolving circumstances) and Principle 21 (requiring formal reporting where business operations or contexts pose risks of severe human rights impacts).

70 Stephens and French, above (n 68), 6.

71 Compare, for example, the gradual increase in the requirements of due diligence in environmental law from the Trial Smelter Arbitration (United States $v$ Canada), (1941) III RIAA 1905) and the more recent Pulp Mills on the River Uruguay (Argentina v Uruguay), Judgment, (2010) ICJ Reports, p 14. 
Since the Tribunal decided the matter ex parte, the true legal position of China is missing. By way of proxy, and so to provide a more holistic analysis of the situation, especially concerning liability for causing harm to the environment, we resort to a study conducted by the Chinese Society of International Law (CSIL). ${ }^{72}$ Regardless of the formal position of China, these legal arguments are significant because they signal the importance of reputational concerns that China should be seen to be acting lawfully in the South China Sea. This shows a wider concern for the rule of law and the values of the international community as a whole.

CSIL came to the following conclusions: The Tribunal had no jurisdiction to the submissions number 11 and 12 (b) of the dispute, and therefore questioned the nature of the due diligence obligation imposed on the PRC by the Tribunal in response to those submissions. ${ }^{73}$ CSIL was of the opinion that the obligation of due diligence imposed on the PRC by the Tribunal was in the form of an obligation of result rather than an obligation of conduct. ${ }^{74}$ In particular, that the Tribunal simply equates the result of damage with the existence of a breach of Articles 192 and 194(1) and (5). ${ }^{75}$ The reasoning is not developed, but earlier reference to the fact that due diligence does not guarantee that harm will not occur, and that the State exercise vigilance in accordance with their capacity, indicates that a threshold of conduct was set too high.

The obligation of conduct does not restrict itself to the act but extends to the means used to carry out those acts, and those means need to be decided in the proportion of the risk involved. This is how the Tribunal interpreted the obligation of due diligence and stated it to be an obligation of conduct. Whereas, an obligation of result means the obligation of due diligence arises from the result caused by the act of the State or by people within its jurisdiction and control. As far as the imposition of the due diligence obligation and the degree of the due diligence obligation applied in this case by the Tribunal is concerned, it must be read with Articles 192 and 194 of the Convention, as it indicates that the due diligence obligation not only relates to the direct activities by the State and activities under States' control, but also to the duty to

72 CSIL, above (n 15$)$.

73 Ibid. On jurisdiction and admissibility see Chapters 2 and 3 respectively, on due diligence see para $782 \mathrm{ff}$.

74 Ibid para 782 .

75 Ibid para 807 . 
ensure that no significant harm to the marine environment is caused by the activities of people within or outside its jurisdiction or control. ${ }^{76}$

In the course of establishing the causal link between the acts of the State and its impact on the marine environment, the Tribunal emphasized the obligation of due diligence, the standard of which is proportional to the risk and is precautionary in nature. ${ }^{77}$ The Tribunal not only found the PRC to be in violation of the provisions of the Convention, but also not to have acted reasonably, which is evident from the Tribunal's subsequent observation that the standard of satisfaction concerning the environmental impact assessment (which are also connected to Article 192) was not satisfactory according to international standards. ${ }^{78}$ This again reinforced the idea that the degree of due diligence the State is required to meet within a given situation must be accompanied with a certain level of vigilance. Moreover, the obligation of due diligence dictates its application ex ante and not post hoc. ${ }^{79}$ Remarking on the wider jurisprudence on due diligence, Brunnée explains that 'it appears as if the ICJ distinguishes between the duty to take diligent steps to prevent significant transboundary harm, which it then deals with under the rubric of separate procedural obligations, and the duty to take diligent steps not to cause harm, which it considers cannot be violated simply by a failure to act diligently' ${ }^{80}$ Therefore, the Tribunal's assertion of the due diligence obligation seemed to deploy the obligation of conduct of the PRC in their observation and the standard of the obligation is determined in proportion of the foreseeable transboundary harm based on the best information available.

Another argument was put forward saying that the obligation of due diligence is flexible in a sense it changes in accordance with the capacity of the States. Quoting the judgment from the Seabed Disputes Chamber in its Advisory Opinion:

$76 \quad$ scs Merits, above (n 6), paras 964, 983-991.

77 T Stephens, International Courts and Environmental Protection (Cambridge University Press, 2009) 158; see also J Crawford, Brownlie's Principles of Public International Law (8th ed, Oxford University Press, 2012) 356-357.

78 scs Merits, above (n 6) para 948.

79 Certain Activities Carried Out by Nicaragua in the Border Area (Costa Rica v Nicaragua), Compensation, Judgment, (2018) ICJ Reports, p 15. See also J Rudall, 'Certain Activities Carried Out by Nicaragua in the Border Area (Costa Rica v. Nicaragua)' (2018) 112 American Journal of International Law 288-294.

80 J Brunnée, 'Procedure and Substance in International Environmental Law: Confused at a Higher Level' (2016) 5(6) ESIL Reflections. 
The content of "due diligence" obligations may not easily be described in precise terms. Among the factors that make such a description difficult is the fact that "due diligence" is a variable concept. It may change over time as measures considered sufficiently diligent at a certain moment may become not diligent enough in light, for instance, of new scientific or technological knowledge. ${ }^{81}$

In this anthropogenic epoch, this explanation can be construed in favour of the Tribunal's judgement. In addition, it works in favour of the imposition of a high standard of due diligence obligation on the States and the entities while executing their duties. The PRC, being competent in various fronts and emerging as the world leader, is expected to be held to high standard. Notably, the CSIL position was that the Tribunal deliberately disregarded the need to factor in the matter of capacity when judging diligence. ${ }^{82}$

As discussed earlier in this chapter, the marine environment of the scs is fragile and crucial for sustaining biological diversity and its potential impact on fighting climate change. Both these activities possess a threat common to the international community, which inspires the Tribunal to hold the State to a higher standard while exercising its due diligence obligation to protect the marine environment for greater common good.

CSIL advanced a further argument challenging the Tribunal's findings that China was in breach of Articles 192 and 194, claiming the Tribunal had misconstrued the meaning of Article 194(5) of the LOSC. In their opinion, interpretation and application of one of the clauses of Article 194 must be done as a whole. Sub-clause 5 of the Article 194 'extends the concept of the protection and preservation of the marine environment to "rare or fragile ecosystems" and the "habitat of depleted, threatened or endangered species and other forms of marine life" .83 According to CsIL, both the title of Article 194 ('Measures to prevent, reduce and control pollution of the marine environment') and the content of first four paragraphs indicate that the measures provided for in Paragraph 5 apply only when they result from 'pollution of the marine environment. ${ }^{4}$ Thus, it emphasized that the pollution of the marine environment is the pre-condition for the application of the provisions of Article 194(5). Further, the study argued that since the Tribunal had not proved that 'harmful

$81 \quad$ Responsibilities and Obligations of States Sponsoring Persons and Entities with Respect to Activities in the Area, Advisory Opinion, 1 February 2011, ITLOs Reports 2011, p 10, para 117.

82 CSIL, above (n 15), para 782 .

83 LosC, above (n 1), Art 194.

84 CSIL, above (n 15$)$, para 790. 
harvesting activities' had caused 'pollution of the marine environment', the application of the Article 194(5) was questionable. ${ }^{85}$ CSIL reaffirmed their view that the obligation of due diligence is an obligation of conduct and the Tribunal disregarded the means taken by PRC in exercising that obligation. As a result, they imposed the obligation on the PRC in pursuance to the result of the activities. It is interesting to note that while the CsIL pressed for a holistic interpretation of Article 194 of the LOSC, they did not take into account the overall object and purpose of the Convention or Part XII of the Convention in particular, which indicated that the protection and preservation of the marine environment is the primary aim of this Convention.

In context of the activities of a State causing environmental harm, the first problem lies in justifying the grounds for bringing the State within the framework of responsibility and the second is the compliance or enforcement of the decision. Therefore, bringing the State within the responsibility framework based on the nature and the impact of the acts of the State and irrespective of them being in violation of an existing convention or treaty is the subject of analysis in this chapter.

Irrespective of the sovereignty dispute about islands, territory or the marine resources, any State which engages in the exploitation of marine resources is under certain obligations towards neighbouring States and the international community. The Tribunal, by nesting Article 194(5), within a wider due diligence commitment to protect the marine environment under Article 192 points towards the connection between the general obligation of the States to protect and preserve the marine environment and the conduct of activities for the exploitation of the marine resources. The nature of the harm occasioned through construction and unsustainable fishing practices are transboundary, and they present to the international community and the future generations a series of known and unknown threats. ${ }^{86}$ As such, such harm should be regarded as a concern common to humankind. ${ }^{87}$ Admittedly, this is a bold claim, but we view this as a frontier that needs to be pushed in order to enhance the

\footnotetext{
85 Ibid para 791.

86 Government of United Kingdom, 'Sustainable Fisheries for Future Generations. The Fisheries White Paper' (Department for Environment, Food and Rural Affairs, 2019).

87 C Bowling, E Pierson and S Ratté, 'The Common Concern of Humankind: A Potential Framework for a New International Legally Binding Instrument on the Conservation and Sustainable Use of Marine Biological Diversity in the High Seas' (2016), http:// www.un.org/depts/los/biodiversity/prepcom_files/BowlingPiersonandRatte_Common_ Concern.pdf.
} 
protection of critical environments. ${ }^{88}$ By categorizing it as such, elevates not only the standards of responsibility, but opens up avenues for collective action by the international community, within the framework of the law on international responsibility. ${ }^{89}$ The following sections will investigate the prospects arising from the doctrine of common concern of humankind and the emergence of correlative international responsibility of the States while affecting the issues of common concern.

Global commons are a common resource for all humankind. They are regulated with certain defined principles of law given the nature, use, and availability of the resource. Arguably, this extends to essential commitments to preservation or conservation of the resource..$^{90}$ The concern for the resource is derived from its inherent value and not just because of its utility to humankind..$^{91}$ This understanding had resulted in establishing the parameters to build a global system to fight the environmental degradation resulting in the creation of a new world order, in the form of the doctrine of common concern of humankind.

\subsection{The Doctrine of the Common Concern of Humankind}

The nature-human interface in the present day has entered a new phase termed the Anthropocene..$^{92}$ This captures new understandings that human activities in the present can cause the change to our planet to an extent comparable to the major geological events of the ancient past, and that these changes may be permanent on the geological timescale. ${ }^{93}$ The significance of human behaviour

88 See, for example, K Zemanek, 'New Trends in the Enforcement of erga omnes Obligations' (2000) 4 Max Planck Yearbook of United Nations Law 1- 52.

89 J Crawford, 'Articles on Responsibility of States for Internationally Wrongful Acts' United Nations Audio-visual Library of International Law (2012), http://legal.un.org/avl/pdf/ha/ rsiwa/rsiwa_e.pdf.

9o E Ostrom, R Gardner and J Walker, Rules, Games and Common-Pool Resources (University of Michigan Press, 1994) 369 .

91 SC Rockefeller, Principles of Environmental Conservation and Sustainable Development: Summary and Survey: A Study in the Field of International Law and Related International Reports (Earth Charter Initiative, 1996) 1, 23, https://earthcharter.org/virtual-library2/ principles-of-environmental-conservation-and-sustainable-development-summary-andsurvey-1996/.

92 See further, Hey, Chapter 19 this volume.

93 J Zalasiewicz, M Williams, W Steffen and P Crutzen, 'The New World of the Anthropocene' (2010) 44(7) Environmental Science and Technology 2228-2231. 
on the environment has ushered in a new geological epoch. ${ }^{94}$ Characterizing the human-nature interface as such has significant consequences for global commons such as climate, air, water and biodiversity. It is the challenge facing us for the management and protection of global commons for the humankind in this century. All of humanity shares the risk from such activities because of the scale of such threat to natural systems is critical for the existence of life. One way of addressing the challenges of global governance in the Anthropocene is through the doctrine of the common concern of humankind.

The concept has its origins in the late twentieth century. In 1987 , the phrase common concern made its appearance in the Report of the World Commission on Environment and Development. ${ }^{95}$ The Chairwoman, Gro Harlem Brundtland, in the preface of the seminal report stressed that diverse nations were united over 'a common concern for the planet and the interlocked ecological and economic threats with which its people, institutions, and governments now grapple. ${ }^{96}$ Throughout the report, a plea for a united effort by the global community to fight the issues of common concern was apparent. As Shelton states, 'issues of common concern are those that inevitably transcend the boundaries of a single State and require collective action in response. ${ }^{97}$ Accordingly, the doctrine of common concern of humankind is mainly about protection, preservation and conservation of the commons. ${ }^{98}$ The notion of this theory is rooted in the concept of reasonableness arising out of necessity and is guided by the spirit of cooperation. ${ }^{99}$ The theory of common concern results in an ideological shift from individualism to collective action. In this vein, the authority over the commons is not restricted to some; the exclusion of others is not arbitrary, based on capacity or historic use. Instead, the regime

94 F Soltau, 'Common Concern of Humankind' in CP Carlarne, KR Gray and R Tarasofsky (eds), The Oxford Handbook of International Climate Change (Oxford University Press, 2016) 203.

95 World Commission on Environment and Development, Our Common Future (Oxford University Press, 1987). The United Nations had created the Commission in 1983, which called for the Secretary-General to appoint a Chairman and Vice Chairman, who would appoint additional members, at least half of whom would come from the developing world. United Nations General Assembly, Report of the World Commission on Environment and Development, UN Doc A/42/427 (4 August 1987), Annex 2: The Commission and its Work.

96 Ibid Chairman's Foreword.

97 D Shelton, 'Common Concern of Humanity, Environmental Law and Policy' (2009) 39(2) Environmental Policy and Law 83 .

98 F Biermann, “Common Concern of Humankind": The Emergence of the New Concept of Environmental Law' (1996) 34(4) Archiv des Völkerrechts 430.

$99 \mathrm{~K}$ Baslar, The Concept of the Common Heritage of Mankind in International Law (Kluwer Law International and Martinus Nijhoff Publishers, 1998) 107-111. 
is designed for equitable sharing of burdens of the commons in their commitment to solving the growing problem of the regulation of commons. In this sense, it represents a new frontier in thinking about how we address shared problems.

The principle of common and shared responsibility rests on the assumption that burden sharing is required by the international community to make social and economic progress, ${ }^{100}$ and to address global issues such as climate change, biodiversity loss, depletion of the ozone layer and even international criminal activities. It is sometimes rooted in the concept of obligations or duties being grounded in the correction of past wrongs, that is, of holding some State to account for their historic acts that have resulted in the deterioration of the global commons. ${ }^{101}$ However, the task of undoing past harmful consequences falls on the present generation and all the States together, regardless of any past share of blame. Realizing such outcomes requires us to frame obligations and shared responsibility towards the global commons in a nuanced, yet viable legal framework.

The preambles to both the 1992 United Nations Framework Convention on Climate Change (UNFCCC) ${ }^{102}$ and 1992 Convention on Biological Diversity $(\mathrm{CBD})^{103}$ endorse this understanding that humankind must proportionally share the concern for the commons. Thus, the UNFCCC states 'change in the Earth's climate and its adverse effects are a common concern of humankind'. Likewise, the conservation of biological diversity is of common concern, not the biodiversity itself. This affirmation is further predicated upon two fundamental principles of international law: the 'no harm rule'104 and 'sustainable use.'105 Article 5 requires cooperation between Contracting Parties, as Barnes notes, the nature of biological diversity is such that a State cannot protect it without cooperative measures since diversity is a quality that transcends State boundaries. ${ }^{106}$ Together, these obligations demonstrate the need for collective action for the protection of the resource, which can be endorsed by conferring

\footnotetext{
100 RP Anand, Confrontation or Cooperation? International Law and Developing Countries (Springer, 1987) 45 .

101 P Sands, J Peel, A Fabra and others (eds), Principles of International Environmental Law (3rd ed, Cambridge University Press, 2012) 233.

$102 \quad 1771$ UNTS 107.

103 CBD, above (n 44).

104 Ibid Art 3.

105 Ibid Art 6.

106 R Barnes, 'Fisheries and Biodiversity' in M Fitzmaurice, D Ong and P Merkouris (eds), Research Handbook on International Environmental Law (Edward Elgar, Cheltenham, 2010) 542-563, 551 .
} 
the status of common concern to the resource. ${ }^{107}$ Although the concern for biological diversity could be argued to be of mere local or regional concern, and therefore subject to national jurisdiction, the impact of activities on components of biological diversity that reduce diversity affect humankind along with the other life forms on our planet. All States gain a de facto benefit from the preservation and conservation of global commons, irrespective of whether the resource lies within their territory or not. ${ }^{108}$ Therefore, constructive cooperation by all the parties sharing the resource is essential.

As far as the conservation of biological diversity is concerned, its jurisdictional scope extends to the biodiversity within the limits of national jurisdiction, and 'in the case of processes and activities, regardless of where their effects occur, carried out under its jurisdiction or control, within the area of its national jurisdiction or beyond the limits of national jurisdiction.' ${ }^{109}$ This commitment extends to the protection of marine biodiversity wherever it is located unless protective measures are clearly in contradiction to the provisions of the LOSC. ${ }^{110}$ Marine biodiversity has been a priority for States Parties to the СвD. In 1995, the Conference of Parties adopted the Jakarta Mandate on Marine and Coastal Biological Diversity. ${ }^{111}$ Other agreements establish general protections for the components of biodiversity such as the listing of endangered species, ${ }^{112}$ restrictions on trade in endangered

107 J Brunnée, 'Common Areas, Common Heritage, and Common Concern', in D Bodansky, J Brunnée and E Hey (eds) The Oxford Handbook of International Environmental Law (Oxford University Press, 2007) 551-572.

108 D Hunter, J Salzman and D Zaelke (eds), International Environmental Law and Policy (3rd ed, Foundation Press 2007) 489.

109 CBD, above (n 44), Art 4.

110 P Birnie, A Boyle and C Redgwell, International Law and the Environment (3rd ed, Oxford University Press, 2009) 750. However, the authors note that whilst Article 22 of the СвD, above ( $\mathrm{n} 44$ ), might serve to ensure that the LOSC commitments prevail, the LOSC can readily be interpreted to include measures to protect marine biodiversity.

111 СвD, Conservation and Sustainable Use of Marine and Coastal Biological Diversity (Jakarta Mandate), Doc CBD/COP/DEC/II/10 Conservation and sustainable use of marine and coastal biological diversity (1995); see in particular, 'Implementation of the Jakarta Mandate on Marine and Coastal Biological Diversity, including the СвD multi-year programme of work on marine and coastal biological diversity', https://www.un.org/depts// los/general_assembly/contributions2004/CBD2004.pdf.

112 The IUCN Red List of Threatened Species is available at https://www.iucnredlist.org. "The IUCN Red List is a critical indicator of the health of the world's biodiversity. Far more than a list of species and their status, it is a powerful tool to inform and catalyze action for biodiversity conservation and policy change, critical to protecting the natural resources we need to survive. It provides information about range, population size, habitat and ecology, use and/or trade, threats, and conservation actions that will help inform necessary conservation decisions'. 
species, ${ }^{113}$ and habitat protective measures. ${ }^{114}$ Other instruments seek to control specific activities that have adverse impacts on marine biodiversity, such as driftnet fishing ${ }^{115}$ or bottom trawling. ${ }^{116}$ A sectoral approach to the protection of marine biodiversity and certain endangered or listed species has had some successes. These measures establish a network of obligation for the protection of the species and habitats and thereby marine biodiversity more generally. However, the effort remains fragmented, especially in areas beyond national jurisdiction. ${ }^{117}$

It is here that the concept of the common concern of humankind can assist, by directing coordinated efforts towards the protection of marine biodiversity and urging the imposition of shared responsibility for issues common to humankind. Common concern entails both negative and positive obligations on the State; negative in a sense that the State should refrain from activities which cause a threat to the concerns common to humankind, and positive, in a sense that the State should take proactive measures to avoid or mitigate the harm caused. ${ }^{118}$ This has led some commentators, such as Desierto, to consider whether the shared responsibility of the international community for the protection of the concerns common to humankind could be stretched to include collective action (through the UN Security Council) by the international community against the offending State? ${ }^{119}$ Here we suggest there are two options that follow from notions of common concern: first the use of the law on State responsibility and obligations owed to the community as a whole, and second, community orientated solutions, such as zones of peace or marine parks.

113 To access Appendix I, II and III and their listed species database, see cITES, 'The CITES Species', https://www.cites.org/eng/disc/species.php; accessed 11 July 2019.

114 Ramsar, 'The Ramsar List of Wetlands of International Importance', https://www.ramsar. $\mathrm{org} /$ sites/default/files/documents/library/sitelist.pdf.

1151989 Convention for the Prohibition of Fishing with Long Driftnets in the South Pacific, (1990) 29 ILM 1449.

116 K Tetzlaff, 'Bottom Trawling on the High Seas: Protection under International Law from Negative Efforts?' (2005) New Zealand Journal of Environmental Law 239-285; see also M Gianni, High Seas Bottom Trawl Fisheries and their Impacts on the Biodiversity of Vulnerable Deep-Sea Ecosystems: Options for International Action (IUCN, 2004).

117 E Druel and KM Gjerde, 'Sustaining Marine Life beyond Boundaries: Options for an Implementing Agreement for Marine Biodiversity beyond National Jurisdiction under the United Nations Convention on the Law of the Sea' (2014) 49 Marine Policy 9o-97.

118 Bowling et al., above (n 87), 11-12.

119 Desierto, above (n 16), 71. 


\section{$5 \quad$ Conflict Management Using the Law of State Responsibility}

The Articles on the Responsibility of States for Internationally Wrongful Acts were adopted in 2001 (ARSIWA). ${ }^{120}$ The ILC made an important innovation in Part Three, Chapter One of ARs IWA with the adoption of Article 48 concerning the invocation of responsibility by a State other than an injured State. Within Article 48(1), the ILC established a category of obligation, which if breached, would entitle another State - any State other than the injured State - to invoke the responsibility of the State for a breach of certain types of an international obligation. Such an obligation was further divided into two categories: (a) the obligation breached is owed to a group of States including that State, and is established for the protection of a collective interest of the group; and (b) the obligation breached is owed to the international community as a whole. ${ }^{121}$ Additionally, by eliminating the requirement of injury for claiming the breach of obligations owed to the international community as a whole, the noninjured States could rightfully make such claims. The ILC specifically referred to the protection of the marine environment in this context. ${ }^{122}$

There is potential for Article 48 to be used to protect a range of collective interests, ranging from human rights to environmental protection. As observed by Wiess, the text of the article includes the term international community as a whole, instead of, international community of the States, as used in the Vienna Convention on the Law of Treaties. ${ }^{123}$ She then argues that this 'formulation conforms with the view that the international community now comprises important actors other than states' ${ }^{\prime 24}$ This enables collective action, thereby opening up new possibilities for the enforcement of international obligations.

Despite its progressive nature and promising endeavours, Article 48 remains a controversial provision because the non-injured State making such a claim need not require a collective or third-party decision in order to invoke responsibility; all it needs is to decide whether the breach was owed to the international community as a whole or not. Thus, eliminating the otherwise necessary element of causation required to link the acts of the State and the harm caused. Neither the Draft Articles nor the Commentary thereto clearly establishes

120 ILC, Articles on Responsibility of States for Internationally Wrongful Acts (ARSIWA), with commentaries, Yearbook of the International Law Commission, 2001, vol II, Part Two.

121 Ibid.

122 Ibid, 127.

123 EB Weiss, 'Invoking State Responsibility in the Twenty-First Century' (2002) 96 American Journal of International Law 798-816, 804.

124 Ibid. 
what comprises this category of obligations or how to reach a decision as to whether such a collective interest has been breached. ${ }^{125}$ However, Part II of ARSIWA deals with the content of international responsibility of a State and in Article 33 it sets out the scope of international obligations of the responsible State. It says that the scope of the obligations arising from Article 33 can be owed to another State, to several States, and to the international community as a whole, and the nature of obligations which can be owed depends on the character and content of the international obligation, as well as the circumstances of the breach. ${ }^{126}$ Article 48 should be read with Article 33 in order to determine the scope and nature of international obligations. We suggest that the issues of marine biodiversity and protection of the marine environment, as discussed in the context of the SCS dispute, comprise such interest.

Here we draw upon the insights of Roeben in his analysis of international responsibility. He argues that international law must ensure 'the duties of responsible actors can be determined in a practical manner. ${ }^{127}$ This includes determining the content and responsibility for 'public goods.' ${ }^{128}$ International political and legal systems having provincial authority over the subject matter are required to identify the content having international public good, as is the means for attribution of responsibility for them. According to Roeben there are two categories of public good: those requiring international cooperation and those requiring internal action (i.e., action by individual States). The former category includes sustainable development and regulation of the global economy. The logic here is that if the conduct cannot be internalized to a State, then it must entail a response through collective mechanisms such as Article 48. The systematic loss of biological diversity, continuous damage to the environment and the change in climatic conditions belongs to this category of public goods. Based on this understanding, arguably, it is the responsibility of international legal and political systems to identify such public goods and develop a mechanism for their protection.

In this context, the theory of common concern of humankind can be utilized as the doctrine to determine what concerns are common to humankind and what obligations are owed to the international community as a whole. ${ }^{129}$

125 ARsiWA, above (n 120) 126; see also F Soltau, 'Common Concern of Humankind' in Carlarne, Gray and Tarasofsy (eds), above (n 96), 207.

126 ARsiWA, above (n 120), Art 33(1).

127 V Roeben, 'Responsibility in International Law' (2012) 16 Max Planck Yearbook of United Nations Law 99-158, 107.

128 Ibid 112.

129 F Soltau, above (n 94), 202, 208. 
To date this process of designating the nature of such interests is incomplete. This is in part because knowledge of the significance of natural systems is still under development, and in part because the political will of States to undertake this exercise is absent. However, as is evident from the foregoing analysis of the sCs dispute, this is a critical process. In the absence of well-defined community interests and collective measures of redress for wrongs framed in bilateral terms, powerful States may be able to resist pressure to rectify their behaviour. Given the current limits here, it seems useful to consider how common concerns might be articulated as solutions outside the context of litigation.

\section{Alternative Solutions to Threats to Common Concerns}

If State responsibility is limited in its capacity to manage conflicts, alternative solutions may be required to secure the protection of interests of shared concern to the international community as a whole. Noting the stalemate following the scs arbitration, a number of commentators proposed alterative solutions to the dispute. What these appear to have in common is that they extol the virtues of strategic cooperation, and seek to refocus the nature of disputes away from sovereignty towards shared (community) concerns.

The first such option is the establishment of a 'peace park'. Environmental groups and activists have proposed the creation of a marine peace park as an alternative mechanism to manage the resources in the disputed area. ${ }^{130}$ Such options have been investigated by the IUCN, who maintain a record of such practices. ${ }^{131}$ Such parks combine both environmental objectives and a peace purpose, so differ from ordinary protected areas. ${ }^{132}$ Examples include the Binational Red Sea Marine Peace Park between Israel and Jordan. ${ }^{133}$ There is no official process for the designation and management of such parks. Although practices exist within domestic fora, these mechanisms cannot work for transboundary initiatives. Ultimately, the creation and maintenance of such a park will depend upon the concerned States reaching agreement. It may be

130 JW McManus, K-T Shao and S-Y Lin, 'Toward Establishing a Spratly Islands International Marine Peace Park: Ecological Importance and Supportive Collaborative Activities with an Emphasis on the Role of Taiwan' (2010) 41 Ocean Development and International Law 270-280.

131 T Sandwith, C Shine, L Hamilton and D Sheppard, Transboundary Protected Areas for Peace and Cooperation (IUCN, 2001).

132 Ibid 4.

133 Ibid 11. 
observed that there is nothing to prevent such agreements being adopted on an ad hoc basis. Other cooperative mechanisms, such as provisional arrangements under Article 74(3) and 83(3) of the LOsC could be used as templates for such agreements. ${ }^{134}$ Although not designed for peaceful purposes, the process of developing stewardship responsibilities for the Sargasso Sea provides another template, and shows the importance of non-State actors in facilitating developments. ${ }^{135}$ There were reports that a motion would be filed with the International Union for Conservation of Nature (IUCN) World Conservation Congress in 2016 to have the disputed area designated a peace park. However, this did not come to fruition. Even if this option is on the table, caution must be exercised over such prospects since any implementing measures might be seen as consolidating claims to sovereignty in the disputed area.

A second option would be to develop the scs into a zone of peace and cooperation, which could encompass measures for the exploitation, conservation and management of the natural resources therein. States in the region could declare the SCS a zone of peace and cooperation under which States would be required to desist from carrying out any activities such as reclaiming the sea, use of the islands and other maritime features for non-peaceful purposes, and appropriation of the sea-bed and water column in the scs. There are legal templates and precedents in international law for the creation of maritime zones of peace and the use of the seas for peaceful purpose. ${ }^{136}$ These include efforts to establish the Indian Ocean as a zone of peace or the South Atlantic as a zone of peace and cooperation or the Mediterranean as a zone of peace and cooperation. ${ }^{137}$ Such zones are not necessarily inconsistent with international law. For example, Article 88 of the LOSC reserves the high seas for use for peaceful purposes. However, like peace parks, there is no formal process for such a designation, and ultimately this depends upon agreement between the interested parties. As discussed by Subedi, a particular challenge for such designations is securing compliance by third parties with any such measures, particularly if such zones extend to high seas areas. ${ }^{138}$

134 See further Churchill, Chapter 5 this volume.

135 See further Gjerde and Varmer, Chapter 17 this volume, and Balton, Chapter 18 this volume.

136 On zones of peace, see SP Subedi, Land and Maritime Zones of Peace in International Law (Clarendon Press, 1996).

137 Ibid chapter 1.

138 Ibid chapter 6; see also, R Barnes, 'Objective Regimes Revisited' (2000) 9 Asian Yearbook of International Law 97-145. 
A final option would be the establishment of a joint development zone. If the States in the region come together to work towards a collective measure, they could agree on joint development of hydrocarbon resources under a framework of sui generis character by setting aside territorial or sovereignty disputes. This idea has been on the table for some time, and many States in different parts of the world have implemented it through bilateral agreements. ${ }^{139}$ It could be done on a bilateral or multilateral basis between the States in the scs, although most of such practice is bilateral. Again, such steps require the agreement of the interested parties.

This chapter proposes two different but compatible ways forward for advancing the common concerns of humankind in the South China Sea: international responsibility for harm to collective interests and the designation of disputed areas as protected areas. It is well-established that marine construction activities and harmful fishing practices can result transboundary environmental harm to the environment. As such, it is desirable to place such activities, and steps to mitigate or avoid them, in a cooperative and collaborative framework. The former permit States to act in the collective interest against wrongdoing States, whereas the latter provide means of avoiding conflict through proactive cooperative management of disputed areas. We suggest that the existing international/domestic legal discipline is not equipped to face the rising challenges. Tightening of the regulatory mechanisms for environmental protection and strengthening international cooperation are essential. This state of affairs calls for a secondary mechanism to make individual States responsible for any breach of obligations owed to the international community. Unless we progress towards and invest in developing this mode of secondary responsibility of the States and make use of international responsibility to maintain international legal order with an object to protect global commons from the harmful impacts of human activities or intervention, we are unlikely to witness a sound basis for global governance of the seas and oceans around the globe. Since the concern is growing, so too must the efforts of international law to develop and

139 Centre for International Law, the National University of Singapore, Selected Documents on Joint Development and the South China Sea (prepared for CIL Conference on Joint Development and the scs, 16-17 June 2011); see also, DM Ong, 'Joint Development of International Common Offshore Oil and Gas Deposits: "Mere" State Practice or Customary International Law?' (October 1999) 93(4) American Journal of International Law 771-804. 
maintain the sustainable legal world order. Given the juncture of geological time scale we exist in, it seems like the direction international law and the global community must progress.

We acknowledge that both of these options are ambitious, and both are heavily predicated upon States having the will to act. If States generally refrain from bilateral litigation, then why is litigation in order to protect common interests any more likely? Again, designating marine protected areas in the common interest will entail States acting in the common good rather than for exclusive, self-interested reasons. These are significant obstacles to progress. However, the literature on the Anthropocene indicates we are entering new frontiers of understanding, and this means that traditional legal frontiers must be challenged. The common concern of humanity offers a point of focus where progress can be made. States do not act merely out of self-interests. They are sensitive to the benefits of strategic co-operation and reciprocity. They are sensitive to reputational concerns. They acknowledge the importance of shared norms of international behaviour. They are motivated by notions of legitimacy and fairness. To reiterate an earlier point, these factors point clearly towards the wider importance of community interests. The South China Sea dispute shows how these concerns come into play, and why creative community orientated solutions are necessary. 